\title{
Tinjauan Hukum Terhadap Kompetensi Peradilan Tata Usaha Negara dalam Menyelesaikan Sengketa Tanah
}

\author{
Ilmu Hukum, Fakultas Hukum Universitas Gorontalo \\ email : martenbungaOgmail.com
}

\begin{abstract}
The scope of land disputes that became the competence of the State Administrative Judicature according to the judicial principle adopted in Indonesia, the implementation of the Decision of the State Administrative Court in the settlement of land disputes.

This research is conducted through normative legal approach (juridical normative), that is how law is utilized as an instrument to realize the application of land dispute resolution mechanism through authority to try State Administration Court. This research uses normative legal research type to identify and analyze legal factor which is an obstacle in the application of legislation, where this study refers to the laws and regulations on land and State Administration Judicature Law, court decisions and other legal materials.

That the State Administration Dispute in the field of land arises because of a written stipulation issued by the State Administration or Administrative Officer containing State Administration law action which in accordance with the prevailing laws and regulations has been concrete, individual and final in the form of land certificate of ownership the right to land issued by the Government. Implementation of the Decision of State Administration which has been decided and has the force of law in practice raises a polemic in the community where the State Administration officials are not willing to carry out the decision of the Administrative Court of the State. This condition is caused because the State Administrative Court is not the executor (executor of the decision) but only as supervisor of the implementation of the decision, for all government actions in order not to violate the law and the role of legal protection for the community.
\end{abstract}

Keywords: State Administrative Court, Land Dispute

\section{PENDAHULUAN}

Pasal 1 ayat (3) Undang-Undang Dasar 1945 dinyatakan bahwa negara Indonesia adalah negara hukum. Dalam negara hukum, setiap tindakan pemerintah dalam menjalankan tugas-tugas pemerintahan dan pembangunan atau dalam rangka merealisir tujuan negara harus memiliki dasar hukum atau dasar kewenangan. Dalam kepustakaan Hukum Tata Usaha Negara, setiap aktifitas pemerintah harus berdasarkan hukum dikenal dengan istilah asas legalitas (legaliteitsbeginsel atau wetmatigheid van bestuur), artinya setiap aktifitas pemerintah harus memiliki dasar pada peraturan perundang-undangan yang berlaku. Tanpa adanya dasar wewenang yang diberikan oleh suatu peraturan perundang-undangan yang berlaku tersebut maka aparat pemerintah tidak memiliki wewenang yang 
dapat mempengaruhi atau mengubah keadaan atau posisi hukum warga masyarakatnya.

Prinsip negara hukum menjamin kepastian, ketertiban dan perlindungan hukum yang berintikan kebenaran dan keadilan. Dalam hal ini kepastian, ketertiban dan perlindungan hukum menuntut, antara lain bahwa lalu lintas hukum dalam kehidupan masyarakat memerlukan adanya alat bukti yang menentukan dengan jelas hak dan kewajiban seseorang sebagai subjek hukum dalam masyarakat.

Salah satu usaha pemerintah untuk menjamin perlindungan keadilan bagi anggota masyarakat ialah dengan cara diwujudkan Peradilan Tata Usaha Negara berdasarkan Undang-undang Nomor 5 Tahun 1986 yang diundangkan pada tanggal 29 Desember 1986, yang kemudian diubah dengan Undang-undang Nomor 9 Tahun 2004. Perwujudan dan penyempurnaan Peradilan Tata Usaha Negara ini dimaksudkan bukan hanya untuk perlindungan serta kepastian hukum bagi anggota masyarakat, tetapi untuk kepentingan administrasi negara agar mendapatkan tempat secara wajar sehingga benturan yang timbul akibat keputusan administrasi negara mendapat penyelesaian yang adil dan menyatu.

Kemudian salah satu bidang yang mengatur tata kehidupan warga negara yang juga tunduk pada hukum adalah bidang Pertanahan/Agraria. Pasal 33 ayat (3) UUD 1945 dan dijabarkan dalam Undang-Undang Pokok Agraria (selanjutnya disebut UUPA) telah mengatur masalah pertanahan di Indonesia sebagai salah satu peraturan yang harus dipatuhi. Salan satu tujuan pembentukan UUPA adalah meletakkan dasar-dasar untuk memberikan kepastian hukum mengenai hak-hak atas tanah bagi seluruh rakyat, yakni melalui kegiatan pendaftaran tanah untuk seluruh wilayah Indonesia yang produknya adalah pemberian alat bukti kepemilikan hak atas tanah/sertifikat hak milik atas tanah.

Penyelesaian sengketa pertanahan dengan pendekatan hukum pada dasarnya kembali didasarkan pada peraturan perundangan yang berlaku, maksudnya semua penyelesaian masalah pertanahan dilakukan dengan menggunakan pendekatan secara yuridis dengan terlebih dahulu diupayakan dengan musyawarah mufakat.

Penyelesaian sengketa pertanahan dengan pendekatan hukum hanya dapat dilakukan apabila peraturan perundang-undangan tersebut dilakukan secara efektif atau dengan kata lain dilakukan penegakan hukum (law enforcement) secara konsekuen, yaitu penegakan hukum dengan memperhatikan unsur kepastian hukum (rechtssiccheit), kemanfaatan (zweckmassigheit) dan keadilan (gerechtigheid).

Salah satu permasalahan yang timbul di masyarakat adalah mengenai eksekusi atas putusan Peradilan Tata Usaha Negara, dimana eksekusi ini lebih cenderung hanya berdasarkan pada kesadaran. Pejabat Tata Usaha Negara atau dengan peneguran berjenjang secara hirarki (floating form) sebagaimana diatur dalam Pasal 116 Undang-undang Nomor 5 Tahun 1986 tentang Peradilan Tata Usaha Negara ternyata tidak cukup efektif memaksa pejabat Tata Usaha Negara melaksanakan putusan Hakim Peradilan Tata Usaha Negara. 
Keputusan-keputusan Pejabat Tata Usaha Negara yang menimbulkan kerugian di pihak masyarakat, merupakan dasar sengketa antara pejabat dengan rakyat. Untuk menyelesaikan sengketa yang terjadi maka pemerintah sudah menyediakan lembaga yang memiliki wewenang untuk itu, yaitu Undang-undang Nomor 5 Tahun 1986 tentang Peradilan Tata Usaha Negara yang telah di ubah menjadi Undang-undang Nomor 9 Tahun 2004 tentang Perubahan Undang-undang Nomor 5 Tahun 1986 tentang Peradilan Tata Usaha Negara.

Keberadaan lembaga Peradilan Tata Usaha Negara merupakan pelaksanaan Pasal 10 ayat (2) Undang-undang Nomor 4 Tahun 2004 tentang Kekuasaan Kehakiman (dahulu Undang-undang Nomor 14 Tahun 1970 tentang Pokok-Pokok Kekuasaan Kehakiman), yang menyatakan bahwa peradilan yang berada di bawah Mahkamah Agung meliputi badan peradilan dalam lingkungan Peradilan Umum, Peradilan Agama, Peradilan Militer dan Peradilan Tata Usaha Negara.

Salah satu hal baru yang terdapat dari pemberlakukan Undangundang Nomor 9 Tahun 2004 tentang Perubahan Undang-undang Nomor 5 Tahun 1986 tentang Peradilan Tata Usaha Negara adalah pemberlakukan lembaga paksa berupa : uang paksa (dwangsom/ astreinte) dan sanksi administrasi serta publikasi putusan hakim yang diatur dalam Pasal 116 Undang-undang Nomor 9 Tahun 2004 tentang Perubahan Undang-undang Nomor 5 Tahun 1986 tentang Peradilan Tata Usaha Negara, Pemberlakuan Dwangsom/ Uang Paksa dalam proses eksekusi sebenarnya adalah merupakan upaya tekanan (secara psikologis), agar terhukum mau mematuhi atau melaksanakan hukuman pokok. Jadi uang paksa adalah merupakan suatu alat eksekusi secara tidak langsung, dan penerapannya di Peradilan Tata Usaha Negara menyangkut mengenai, jenis putusan apa saja yang dapat dikenai hukuman uang paksa, kepada siapa uang paksa dibebankan dan sejak kapan uang paksa tersebut diberlakukan, hal ini tentunya akan mengurangi pesimisme masyarakat pencari keadilan terhadap eksistensi Peradilan Tata Usaha Negara sebagai lembaga kontrol terhadap Pemerintah sekaligus sebagai perlindungan hukum bagi masyarakat.

\section{METODE PENELITIAN}

Penelitian ini dilakukan melalui pendekatan hukum normatif (yuridis normative), yakni bagaimana hukum didayagunakan sebagai instrumen mewujudkan penerapan mekanisme penyelesaian sengketa tanah melalui kewenangan mengadili Peradilan Tata Usaha Negara. Penelitian ini menggunakan tipe penelitian hukum normatif (normative legal research) untuk mengidentifikasi dan menganalisi faktor hukum yang menjadi kendala dalam penerapan peraturan perundang-undanga, dimana penelitian ini mengacu kepada peraturan perundangan-undangan tentang pertanahan dan Undang-undang Peradilan Tata Usaha Negara, putusan pengadilan dan bahan hukum lainnya.

Bahwa penelitian ini hanya dilakukan dengan studi dokumen yaitu menemukan dan mengetahui asas-asas hukum, pasal-pasal peraturan perundang-undangan yang berlaku, teori-teori hukum, doktrin-doktrin 
hukum, yurisprudensi, filsafat hukum dan hal-hal yang relevan dan menunjang terhadap kualitas dan kesempurnaan penelitian ini.

Analisis data merupakan hal yang sangat penting dalam suatu penelitian dalam rangka memberikan jawaban terhadap masalah yang diteliti, sebelum analisis data dilakukan, terlebih dahulu diadakan pengumpulan data, kemudian dianalisis secara kualitatif dan ditafsirkan secara logis dan sistematis, terhadap asas-asas hukum sistem-sistem hukum dan sinkronisasi hukum dengan menggunakan metode berpikir deduktif dan induktif. Maksudnya kaidah-kaidah yang benar dan tepat diterapkan menyelesaikan suatu permasalahan dari kasus ke kasus yang akan membantu penelitian ini khususnya dalam taraf konsistensi, serta konseptual dengan prosedur dan tatacara sebagaimana yang telah ditetapkan oleh asas-asas hukum yang berlaku umum dalam perundangundangan.

\section{PEMBASAHAN}

A. Ruang lingkup sengketa pertanahan yang menjadi kompetensi Peradilan Tata Usaha Negara menurut asas peradilan yang dianut di Indonesia

Kewenangan absolut peradilan/ atribusi kewenangan (attributie van rechtsmacht) adalah menyangkut tentang pembagian wewenang antar badan-badan peradilan berdasarkan jenis lingkungan pengadilan, misalnya pembagian antara wewenang peradilan Tata Usaha Negara dan Peradilan Umum Kewenangan mengadili (kompetensi absolut) antara Peradilan Tata Usaha Negara (Pasal 47) dan Peradilan Umum (Pasal 50) UU NO 2 tahun 1986 dalam pelaksanaannya seringkali bersinggungan. Pada satu pihak Peradilan Umum mengadili suatu perkara perdata di bidang pertanahan yang berkaitan dengan aspek hak atas tanahnya, dimana sertifikat hak atas tanahnya sebagai salah satu alat bukti, dan pada pihak lain Peradilan Tata Usaha Negara juga memeriksa, memutus dan menyelesaikan sengketa tata usaha negara yang berkaitan dengan aspek prosedur pendaftaran tanahnya, dimana sertifikat, Surat Keterangan Tanah (SKT) dan Surat Keterangan Ganti Rugi (SKGR) yang dimaksud sebagai objek sengketanya menurut Pasal 1 butir 3 UU Nomor 5 Tahun 1986 Jo. UU Nomor 9 Tahun 2004).

Selain Pasal 1 butir 3 UU Nomor 5 Tahun 1986 Jo. UU Nomor 9 Tahun 2004) sebagai objek gugatan dalam sengketa pertanahan di Peradilan Tata UsahaNegara, juga menyangkut permohonan penerbitan sertifikat atau pemberian hak yang ditolak oleh Badan Pertanahan Nasional sebagaimana bunyi Pasal 3 UU Nomor 5 Tahun 1986 Jo. UU Nomor 9 Tahun 2004. Misalnya sengketa mengenai pembatalan surat keputusan pemberian hak atas tanah atau sertifikat hak atas tanah atau keputusan yang berisikan penolakan atas permohonan surat keputusan pemberian hak atas tanah atau keputusan yang berisikan penolakan atas permohonan surat pemberian hak atas tanah atau surat keputusan tentang balik nama atau keputusan berupa penolakan atas permohonan untuk memperoleh sertifikat hak atas tanah yang dikeluarkan oleh Kepala Kantor Wilayah Badan Pertanahan Propinsi 
atau oleh Kepala Kantor Pertanahan Propinsi atau oleh Kepala Kantor Pertanahan Kabupaten/Kotamadya.

Kemudian lebih lanjut diatur pada Pasal 50 Jo Pasal 51 UU Nomor 2 Tahun 1986 yang menentukan Pengadilan Negeri dan Pengadilan Tinggi (Peradilan Umum) bertugas dan berwenang memeriksa, memutus dan menyelesaikan perkara perdata. Dengan demikian Peradilan Umum berwenang mengadili sengketa-sengketa pertanahan yang mengandung aspek hukum perdata. misalnya kepemilikan atau penguasaan tanah secara melawan hukum tindakan yang memperkosa hak milik atas tanah, perbuatan ingkar janji jualbeli, sewa-menyewa, jaminan dan lain-lain hak atas tanah.

Peradilan Tata Usaha Negara memiliki kewenangan absolut mengadili sengketa tata usaha negara. Sengketa Tata Usaha Negara adalah sengketa yang timbul dalam bidang Tata Usaha Negara antara orang atau badan hukum perdata dengan badan atau pejabat tata usaha negara baik dipusat maupun di daerah sebagai akibat dikeluarkannya suatu keputusan tata usaha negara, termasuk sengketa kepegawaian berdasarkan peraturan perundang-undangan yang berlaku.

Berdasarkan Pasal 53 ayat (1) Undang-undang Peradilan Tata Usaha Negara menyatakan bahwa setiap orang atau badan hukum perdata yang merasa kepentingannya dirugikan karena dikeluarkan atau tidak dikeluarkannya suatu sertifikat hak atau surat keputusan pemberian hak atas tanah oleh badan atau pejabat kantor pertanahan dapat mengajukan gugatan ke Pengadilan Tata Usaha Negara dan gugatan tersebut harus diajukan dalam bentuk tertulis.

Berdasarkan Pasal 115 Jo Pasal 119 UU Nomor 5 Tahun 1986 Jo. UU Nomor 9 Tahun 2004, putusan yang telah berkekuatan hukum tetap akan dilaksanakan secara adminstratif di bawah pengawasan Ketua Pengadilan Tata Usaha Negara. Tatacara pelaksanaan putusan tersebut tergantung dari kewajiban yang dibebankan kepada Tergugat sebagaimana tercantum dalam Pasal 97 ayat (9) UU Nomor 5 Tahun 1986 Jo. UU Nomor 9 Tahun 2004.

Uraian proses penyelesaian sengketa pertanahan di Peradilan Tata Usaha Negara yang baik adalah adanya ketentuan yang menjamin bahwa roda pengadilan dapat berjalan lancar, dengan perkataan lain agar penetapan oleh pengadilan tentang bagaimanakah hukumnya dalam perkara yang dihadapkan kepadanya itu dapat diperoleh dalam waktu yang sesingkat-singkatnya, penetapan tentang apakah hukum itu berjalan dengan adil, tidak berat sebelah dan biaya yang diperlukan untuk memperoleh keputusan pengadilan itu beserta realisasinya tidak terlampau memberatkan para pencari keadilan, karena hukum acara itu sifatnya mengabdi kepada hukum materiel, maka dengan sendirinya setiap perkembangan dalam hukum materiel itu selalu diikuti dengan penyesuain hukum acara yang berlaku.

Sengketa pertanahan mempunyai titik singgung antara aspek hukum tata usaha negara dan aspek hukum perdata, dipandang sebagai suatu sengketa atau perkara yang bersifat khas atau unik, dengan demikian telah terjadi perubahan-perubahan dalam situasi 
sosial yang menimbulkan kebutuhan-kebutuhan baru maka kebutuhan itu akan diakomodasikan dengan cara melakukan peninjauan dan penaatan kembali terhadap peraturan-peraturan formil yang ada.

Kemudian timbul pemikiran bahwa selain dari proses satu badan peradilan, jika dikaitkan dengan kerangka berpikir positivisme bahwa pengaturan tentang pembagian kewenangan absolut antara Peradilan Tata Usaha Negara dan Peradilan Umum harus dilaksanakan sesuai dengan norma hukum positif yang sudah ada. Hukum positif tidak boleh diganggu gugat sekalipun dalam pelaksanaannya terdapat ketimpangan-ketimpangan yang menghambat terciptanya keadilan dan kepastian hukum.

B. Pelaksanaan Putusan Peradilan Tata Usaha Negara Dalam Penyelesaian Sengketa Tanah

Peradilan Tata Usaha Negara telah menjalankan peran lebih kurang dalam kurun 14 (empat belas) tahun sebagaimana mestinya sebagai sarana publik dan badan hukum perdata guna melakukan kontrol yuridis terhadap keputusan-keputusan tertulis pejabat Tata Usaha Negara.

Dalam pelaksanaannya ternyata masih ada keputusan-keputusan sengketa Tata Usaha Negara yang telah diputus dan mempunyai kekuatan hukum tetap namun penetapannya tidak terlaksana. Hal inidisebabkan karena masih adanya pejabat publik yang masih sangat memprihatinan kesadaran maupun kepatuhannya terhadap hukum itu sendiri. Sesuai dengan hukum acara yang ada dan karakteristik Peratun bahwa PTUN bukan sebagai eksekutor (pelaksana putusan) tetapi hanya sebagai pengawas pelaksanaan putusan. Sedangkan yang berkewajiban sebagai eksekutor/pelaksana penetapan adalah pejabat publik itu sendiri.

Pengadilan Tata Usaha Negara merupakan institusi peradilan yang paling bungsu di Indonesia, oleh karena itu penegakan hukum melalui institusi ini akan dilakukan secara bertahap karena masih terdapat kekurangan. Pemerintah atau pembuat kebijakan harus memperhatikan sarana dan prasarana untuk mendukung terlaksananya penegaan hukum terhadap putusan Tata Usaha Negara.

Pengadilan Tata Usaha Negara, telah banyak memeriksa dan memutus perkara mengenai keputusan dibidang pertanahan dan pemberhentian dari jabatan bagi pihak yang melakukan kesalahan dalam menjalankan tugas dan jabatannya. Dalam pelaksanaan keputusan Tata Usaha Negara tersebut banyak terjadi polemik dimana ada pejabat yang tidak mau menjalankan putusan Pengadilan Tata Usaha Negara tersebut.

Pada hakekatnya putusan hakim merupakan syarat tentang penegakan hukum dan keadilan. Bila dalam putusan itu terdapat isyarat disisihkannya ketentuan dari suatu undang-undang dalam kasus konkrit, maka pembentuk undang-undang bersama dengan pemerintah harus cepat tanggap, apakah ada yang tidak cermat dalam undang-undang tersebut. Apabila setelah dipertimbangkan dan 
ternyata putusan itu mengandung kebenaran hendaknya pembuat undang-undang cepat merevisi peraturan tersebut.

Tantangan yang dihadapi oleh Pejabat Tata Usaha Negara cukup memperihatinkan terutama karena pejabat Tata Usaha Negara yang mengabaikan nilai-nilai moral dan budaya kerja. Oleh karena itu perlu segera dikembangkan budaya kerja aparatur demi terwujudnya kesejahteraan dan pelayanan masyaraat secara baik dan benar.

Keberadaan Peradilan Tata Usaha Negara sebagai lembaga kontrol yuridis terhadap keputusan pejabat publik bahwa pejabat publik melakukan langkah-langkah yang tidak rasional, misalnya sebagai permohonan eksekusi diminta untuk membuat permohonan pembatalan SHGB yang merugikan pihak Penggugat. Selanjutnya putusan Pengadilan Tata Usaha Negara kurang efektif karena putusannya/ penetapannya tidak dipatuhi pejabat (tergugat), sebab, Peradilan Tata Usaha Negara tidak proaktif terhadap hasil keputusan/ penetapan yang tidak dilaksanakan oleh Pejabat Tata Usaha Negara. Walaupun putusan tersebut tidak dilaksanakan Peradilan Tun hanya diam saja.

Putusan Pengadilan Tata Usaha Negara sebagai lembaga kontrol yuridis ada yang dipatuhi dan ada yang tidak dipatuhi, tetapi lebih banyak yang tidak dipatuhi karena kurang efektif, bahkan pejabat publiknya saja yang tidak menghormati eksistensi badan peradilan, maka harus diaktifkan fungsi Menteri Pendayagunaan Aparatur Negara, dan ditingkatkan lagi fungsi pengawasan kepada penguasa eksekutif.

Ketentuan eksekusi putusan Pengadilan Tata Usaha Negara dalam Undang-undang Nomor 5 Tahun 1986 diatur pada bagian Kelima mengenai pelaksanaan putusan pengadilan dalam Pasal 115 sampai dengan Pasal 119. Pasal 115 menyebutkan : "Hanya putusan pengadilan yang telah memperoleh kekuatan hukum tetap yang dapat dilaksanakan." Pada saat itu suatu sengketa hukum harus berakhir (litis finiri opertet). Apabila sudah tidak ada upaya hukum biasa lagi yang dapat digunakan berarti Putusan Pengadilan dalam lingkungan Peradilan Tata Usaha Negara (termasuk putusan dengan acara singkat menurut Pasal 63) telah mempunyai kekuatan hukum tetap (inkracht van gewijsde) dan memperoleh kekuatan mengikat (rejudicate proveritate kabetur).

Putusan Pengadilan dalam lingkungan Peradilan Tata Usaha Negara yang telah memperoleh kekuatan hukum tetap adalah putusan publik, yang berarti putusan pengadilan tersebut berlaku juga bagi pihak-pihak yang berada diluar sengketa (ergaomnes). Putusan Pengadilan diambil untuk memutuskan perkara yang diserahkan kepadanya dalam rangka apa yang dinamakan "Jurisdictio Contentiosa".

Mekanisme eksekusi putusan Pengadilan Tata Usaha Negara melalui instansi atasan ditetapkan apabila adanya putusan yang berisi kewajiban sebagaimana yang ditentukan dalam Pasal 97 ayat (9) sub b dan c, Pasal 97 ayat (10), dan Pasal 97 ayat (11), maka diterapkanlah ketentuan eksekusi putusan menurut ketentuan Pasal 116 ayat (3) 
sampai ayat (6), yaitu dalam hal Badan atau Pejabat Tata Usaha Negara ditetapkan harus melaksanakan kewajiban sebagaimana tersebut dalam amar putusan untuk menerbitkan Keputusan Tata Usaha Negara, tetapi ternyata setelah 3 (tiga) bulan lewat dan kewajiban itu tidak dipenuhi, maka Penggugat mengajukan permohonan kepada Ketua Pengadilan yang berwenang agar pengadilan memerintahkan Tergugat melaksanakan putusan pengadilan tersebut. Jika tergugat masih tetap tidak mau melaksanakannya, maka Ketua Pengadilan mengajukan hal itu kepada instansi atasannya menurut jenjang jabatan. Instansi atasan ini dalam waktu 2 (dua) bulan setelah menerima pemberitahuan dari Ketua Pengadilan harus sudah memerintahkan Badan atau Pejabat Tata Usaha Negara yang berkewajiban menerbitkan Keputusan Tata Usaha Negara untuk melaksanakan Putusan Pengadilan. Apabila ternyata instansi atasan tersebut tidak mengindahkan pemberitahuannnya, maka Ketua Pengadilan mengajukan hal ini kepada Presiden sebagai pemegang kekuatan pemerintahan tertinggi untuk memerintahkan Badan atau Pejabat Tata Usaha Negara tersebut melaksanakan Putusan Pengadilan yang bersangkutan. Cara eksekusi seperti ini merupakan mekanisme "eksekusi hierarkis."

Ketentuan Padal 116 ayat (3) dan (4) Undang-undang Nomor 6 Tahun 1986 Jo Undang-undang Nomor 9 Tahun 2004, yang berkaitan dengan kewenangan Pengadilan Tata Usaha Negara dengan masalah Eksekusi putusan hanya berupa "memerintahkan terguggat melaksanakan putusan pengadilan tersebut dan mengajukan hal ini kepada instansi atasannya menurut jenjang jabatan, sedangkan wewenang Ketua Pengadilan dalam kaitannya dalam eksekusi putusan pengadilan terbatas hanya mengawasi pelaksanaan putusan yang memperoleh kekuatan hukum tetap. Pada dasarnya eksekusi di Pengadilan Tata Usaha Negara menekankan pada rasa self respect dan kesadaran hukum dari pejabat tata usaha negara terhadap isi putusan hakim untuk melaksanakannya dengan sukarela tanpa adanya pemaksaan (dwang middelen) yang langsung dapat dirasakan dan dikenakan oleh pihak pengadilan terhadap Pejabat Tata Usaha Negara yang bersangkutan.

Ketiadaan upaya paksa dalam eksekusi putusan Pengadilan Tata Usaha Negara yang memang tidak diatur dalam Undang-undang Nomor 5 Tahun 1986 adalah merupakan hambatan yuridis yang akan timbul dalam praktik pada peradilan Tata Usaha Negara sehubungan dengan eksekusi putusan Pengadilan Tata Usaha Negara tersebut.

Dalam praktek putusan Pengadilan Tata Usaha Negara itu sulit dilaksanakan, karena adanya budaya hukum Pejabat Tata Usaha Negara yang belum tumbuh sebagaimana mestinya sebagai pengemban kekuasaan publik hendaknya dalam moral segenap Pejabat Tata Usaha Negara harus sudah merupakan budaya bahwa kekuasaan yang disandangnya adalah kekuasaan rakyat yang dipercayakan kepadanya sehingga harus dilaksanakan sebaik-baiknya.

Dalam prakteknya khususnya dalam pelaksanaan Keputusan Tata Usaha Negara yang berkekuatan hukum tetap banyak yang tidak 
dilaksanakan oleh Pejabat Tata Usaha Negara. Hal tersebut memungkinkan terjadi dalam berbagai aspek interaksi antara pejabat selaku pemegang kekuasaan pelayanan publik dengan warga negara yang membutuhkan pelayanan yang terkait dengan kasus-kasus KKN sehingga berakibat lahirnya keputusan-keputusan pejabat publik secara bertentangan dengan perundang-undangan yang berlaku, penyalahgunaan wewenang (detournament de pouvoir) atau lahirnya putusan pejabat publik yang sewenang-wenang.

\section{KESIMPULAN DAN SARAN}

A. KESIMPULAN

1. Bahwa Sengketa Tata Usaha Negara dibidang pertanahan timbul disebabkan karena suatu penetapan tertulis yang dikeluarkan oleh Badan atau Pejabat Tata Usaha Negara yang berisi tindakan hukum Tata Usaha Negara yang berdasarkan peraturan perundangundangan yang berlaku telah bersifat konkrit, individual dan final dalam bentuk sertifikat tanah mengenai kepemilikan hak atas tanah yang dikeluarkan Pemerintah, dalam hal ini Badan Pertanahan Nasional selaku Badan Tata Usaha Negara yang ditujukan kepada seseorang atau badan hukum (konkret, individual) yang menimbulkan akibat hukum pemilikan atas sebidang tanah yang tidak memerlukan persetujuan lebih lanjut dari instansi atasan atau instansi lain (final). Dimana kewenangan mengadili (kompetensi absolut) antara Peradilan Tata Usaha Negara dan Peradilan Umum dalam memeriksa, memutus dan menyelesaikan suatu sengketa pertanahan tersebut ditentukan dari objectum litis fundamentum petendi (pokok sengketanya) yang bertujuan untuk pembatalan surat keputusan pemberian hak atas tanah atau sertifikat hak atas tanah atau keputusan yang berisikan penolakan atau permohonan untuk memperoleh sertifikat hak atas tanah yang dikeluarkan oleh Kepala Kantor Wilayah Badan Pertanahan atau oleh Kepala Kantor Pertanahan Kabupaten/Kotamadya.

2. Pelaksanaan Keputusan Tata Usaha Negara yang telah diputus dan mempunyai kekuatan hukum dalam prakteknya menimbulkan polemik dimasyarakat dimana pejabat Tata Usaha Negara ada yang tidak mau menjalankan putusan Pengadilan Tata Usaha Negara tersebut. Kondisi ini disebabkan karena Pengadilan Tata Usaha Negara bukan sebagai eksekutor (pelaksana putusan) tetapi hanya sebagai pengawas pelaksanaan putusan, atas segala tindakan pemerintahan agar tidak melanggar hukum dan peran perlindungan hukum bagi masyarakat. Peran pengawasan dan perlindungan hukum ini akan berjalan optimal apabila ditaatinya putusan peradilan Tata Usaha Negara oleh Badan/Pejabat Tata Usaha Negara itu sendiri. Sedangkan yang berkewajiban sebagai eksekutor/pelaksana penetapan adalah pejabat publik, hal ini terjadi karena adanya kesalahan dalam mengaplikasikan asas dan sistem dalam kehidupan berbangsa dan bernegara serta budaya kerja Pejabat Tata Usaha Negara yang mengabaikan nilai-nilai moral dan budaya kerja. Oleh karena itu untuk mengatasi permasalahan 
dalam melaksanakan putusan Pengadilan Tata Usaha Negara tersebut diperlukan terobosan hukum, persepsi, pola pikir dan mengubah perilaku yang dilakukan dengan menumbuh kembangkan nilai-nilai budaya kerja sesuai dengan pengembangan ilmu pengetahuan dan teknologi, yaitu dengan cara Peningkatan Kinerja Aparatur Baik Secara Individu dan Secara Nasional dalam Melaksanakan Tugas dan Tanggung jawab, Prosedur Secara Normatif dan Penangguhan Pelaksanaan Petugas Pengadilan Tata Usaha Negara, Upaya Pemberdayaan Pejabat Tata Usaha Negara, Kebijakan dan Strategi Pendayagunaan Pejabat Tata Usaha Negara, AAUPB Sebagai Alat Penguji Keabsahan dan Alat Untuk Membatalkan Keputusan Tata Usaha Negara, Lembaga Juru Sita, Penerapan Eksekusi Putusan berupa Pembayaran sejumlah uang Paksa (Dwangsom), Penjatuhan Sanksi Administrasi dan Penjatuhan Sanksi Publikasi di Media Massa.

B. SARAN

1. Agar kedepannya dirumuskan oleh pembuat undang-undang bahwa dalam setiap penyelesaian sengketa pertanahan yang mengandung aspek hukum tata usaha negara dan hukum perdata keseluruhannya merupakan kompetensi Peradilan Tata Usaha Negara sebagai lembaga yang monolostik dalam memeriksa, memutus dan menyelesaikan suatu sengketa pertanahan, hal ini diperlukan untuk mendapatkan kebenaran materil yang memberikan perlindungan hukum kepada orang atau badan hukum perdata guna mendapatkan keadilan dan kepastian hukum, maka perlu revisi terhadap UU NO 5 tahun 1986 yo UU no 9 tahun 2004

2. Perlu ditingkatkan kewibawaan Peradilan Tata Usaha Negara dengan cara:

a) Meningkatkan sarana dan prasarana yang mendukung terciptanya peradilan yang cepat, sederhana dan biaya ringan bagi masyarakat pencari keadilan, sehingga makin dipercaya oleh masyarakat.

b) Meningkatkan profesionalisme hukum aparatur Peradilan Tata Usaha Negara, mulai dari hakim hingga staff peradilan, dengan menggadakan diklat-diklat teknis dan keahlian.

c) Makin meningkatkan intensitas penyuluhan hukum, baik kepada aparatur pemerintahan maupun kepada masyarakat.

\section{REFERENSI}

Abdurrahman, Riduan Syahrani, Hukum dan Peradilan, Bandung : Alumni, 1987.

Abdurrahman, Beberapa Aspekta tentang Hukum Agraria, Bandung : Alumni, 1980.

Adi Mansar, Hukum Tanah, Panduan Bantuan Hukum di Indonesia, Jakarta : Sentralisme Production, 2006.

Basah, Sjahcran, Hukum Acara Pengadilan dalam Lingkungan Peradilan Administrasi, Jakarta : Rajawali, 1989.

Baharuddin Lopa, Hamzah, Mengenal Peradlan Tata Usaha Negara, Jakarta : Sinargrafi, 1993. 
Boedi Harsono, Hukum Agraria Indonesia, Sejarah Pembentukan Undangundang Pokok Agraria, Isi dan Pelaksanaannya, Jilid 1 Hukum Tanah Nasional, Jakarta : Djambatan, 1999.

CST Cansil, Modul Hukum Administrasi Negara, Jakarta : PT. Pradnya Paramita, 2004.

Departemen Pendidikan dan Kebudayaan, Kamus Besar Bahasa Indonesia, Jakarta : Balai Pustaka, 1996.

Djoko Prakoso, Peradilan Tata Usaha Negara, Yogyakarta : Litbang, 1983.

Soetrisno, Tatacara Perolehan Tanah Untuk Industri, Jakarta : Rineka Cipta, 2004.

Undang Undang Nomor 5 tahun 1960 tentang Undang-undang Pokok Agraria.

Undang Undang Nomor 5 Tahun 1986 tentang Peradilan Tata Usaha Negara.

Undang-undang Nomor 9 Tahun 2004 tentang Perubahan Undang Undang Nomor 5 Tahun 1986 tentang Peradilan Tata Usaha Negara 